ELORE (ISSN 1456-3010), vol. 20 - 1/2013.

Julkaisija: Suomen Kansantietouden Tutkijain Seura ry.

[http://www.elore.fi/arkisto/1_13/leppalahti2.pdf]

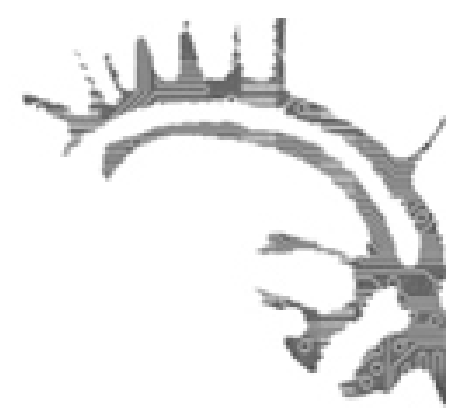

\title{
KIRJA-ARVIO
}

\section{KIINNOSTAVIA KERTOMUKSIA KUMMITTELUSTA}

LAMBERG, MARKO (toim.) 2012: Pä̈̈tön ritari. Kaubutarinoita keskiajalta. Helsinki: SKS. 326 sivua.

\section{Merja Leppälahti}

Sekä keskiaika että kauhuviihde ovat tällä hetkellä kovin suosittuja, joten ei ole syytä ihmetellä, että myös kokoelma keskiaikaisia kauhutarinoita on julkaistu suomalaisten lukijoiden iloksi ja mielenvirkistykseksi. Marko Lamberg on koonnut Päätön ritari -teokseen lähes viisikymmentä kertomusta, jotka ovat peräisin läntisestä Euroopasta, myös Pohjoismaista. Suomalaisiakin tarinoita on mukana; näitä on kirjannut talteen birgittalaisveli Jöns Budde 1400-luvulla.

Lamberg muistuttaa, että luku- ja kirjoitustaito kuuluivat keskiajalla vain harvoille. Kansan parissa kerrotut tarinat liikkuivat vain suullisesti, eikä niitä juurikaan kirjoitettu muistiin. Yksittäisiä piirteitä niistä saattoi kuitenkin siirtyä kirjoitettuihin tapauksiin. Kirjalliset muistiinpanot samastakin tapauksesta voivat vaihdella, sillä ne kirjoitettiin käsin ja kirjoittaja saattoi unohdusten ja väärinymmärrysten lisäksi myös jättää pois epäolennaiseksi mieltämiään seikkoja tai lisätä omia kommenttejaan.

Keskiaikainen kirjallisuus oli luonteeltaan ylirajaista, toisin sanottuna tarinat levisivät käännöksinä mukautuen paikallisiin käsityksiin. Lamberg on suomentanut kirjaan kootut kertomukset alkuteoksista, varhaisista painotuotteista tai niihin perustuvista lähde-editioista. Suomennokset on pyritty tekemään mahdollisimman sanatarkasti, mutta runomuotoiset tekstit on käännetty proosamuotoon. Teksteissä siten todella näkyy keskiaikainen kerrontatapa. Osa tarinoista on peräisin keskiaikaa myöhäisemmältä 
ajalta, mutta toimittajan mukaan ne kuitenkin sisältävät sellaisia piirteitä, että niiden voi katsoa kuvastavan jotain keskiaikaisista kertomuksista.

\section{KIRKKO JA KUMMITUKSET}

Esikristillisellä ajalla pelättiin vainajia ja kammottiin ajatusta kuolleiden näkemisestä. Kertomukset vainajien kohtaamisesta elivät sitkeästi kansanuskomuksissa ja tarinoissa, vaikka kirkkoisä Augustus oli 400-luvulla vakuuttanut, etteivät kuolleet voi millään tavoin vaivata eläviä.

Keskiajan kristillinen teologia taipui myöntämään kummittelun mahdolliseksi. Kristillisen näkemyksen mukaan kummituksia oli jopa useammanlaisia. Ensinnäkin olivat autuaat sielut, jotka saattoivat halutessaan ilmestyä kenelle tahtovat. Kiirastulessa piinattavina olevat sielut näyttäytyivät joskus, kun enkelit sen sallivat. Helvetissä palavat sielut eivät periaatteessa voineet ilmestyä ihmisille. Tällainen sielu saattoi näyttäytyä vain aivan poikkeustapauksessa, lähinnä pyhimysten rukousten vuoksi. Useimmiten tällaisen sielun ilmestyessä jollekulle unessa tai valveilla kysymyksessä oli todellisuudessa kyseisen sielun hahmon ottanut paholainen.

Monet kummittelutarinat kirjoitettiin muistiin kirkon piirissä, esimerkiksi luostareissa. Tällöin asiaan kuului, että nähty vainaja kertoi tai muuten osoitti huonon elämänsä tähden osakseen tulleen piinan ja pyysi rukouksia ja messuja puolestaan. Vaihtoehtoisesti vainaja antoi ohjeita elävälle, jotta tämä pääsisi kuoltuaan autuuteen.

Tuonpuoleisesta saatettiin myös pyytää apua. Silloin käännyttiin pyhimysten puoleen, ja suopeassa tapauksessa pyhimys saattoi näyttäytyä. Eläville ilmestyvät vainajat olivat useimmiten ulkonäöltään kauheita, mutta pyhimykset olivat tavattoman kauniita. He esiintyivät joko eläessään käyttämiensä kaltaisissa puvuissa tai puhtautta symboloivissa valkeissa vaatteissa. Kirjassa on mukana useita kertomuksia Vadstenan Katariinasta, Pyhän Birgitan tyttärestä, jota Suomessakin kunnioitettiin.

\section{MUITA KUMMITUKSIA}

Kaikki keskiaikaiset kummittelutarinat eivät kuitenkaan edustaneet pelkästään hengenmiesten näkökulmaa. Mukana on esimerkiksi myös kaksi kuningas Arturin aikaan sijoittuvaa kertomusta, joista toisessa kyllä nimenomaan kehotetaan tekemään parannus. Toisen Lamberg on nimennyt otsikolla "Päätön ritari”. Kysymyksessä on 1300-luvulle ajoitettu runoteos "Sir Gawain and the Green Knight". Pitkä, 70-sivuinen tarina erottuu muista pituutensa lisäksi myös yksityiskohtiensa runsaudessa; päähenkilöiden loisteliaita asuja ja metsästyksen verisiä yksityiskohtia kuvaillaan huolellisen tarkasti. Hyveellisyys on kunniassaan, ja kertomuksessa on selvä opetus, mutta selvästi tarinalla on myös ollut vahva viihdearvo.

Selvimmin ei-kristilliseen maailmaan sijoittuvat islantilaiset kertomukset. Tosin niihinkin on liitetty kristillisiä huomautuksia ja Islantiin on keskiajalla jopa sijoitettu 
helvetin tai kiirastulen sisäänkäynnit. Näissä tarinoissa kuollut kuningas voi palata kumpuhautaansa kohtaamaan elävän morsiamensa viimeisen kerran, mutta ystävänsä kanssa vapaaehtoisesti haudattu voi myös joutua puolustautumaan hillittömän lihan- ja verenhimoisen vainajan hyökkäyksiltä.

Tarina äidistä, joka palaa haudasta pyytämään, ettääitipuoli kohtelisi paremmin hänen lapsiaan, on 1500-luvun lopun tanskalaisesta balladista. Kertomuksessa on kuitenkin elementtejä, jotka osoittavat sen kuuluvan keskiajan katoliseen maailmaan. Tarinaa on kerrottu suullisesti jo ennen sen tallennusta jalosukuisen rouvan Karen Brahen laulukirjaan, ja siitä on olemassa monia toisistaan poikkeavia versioita.

Päätön ritari osoittaa, että keskiaikaisissa kummittelutarinoissa esiintyy monenlaisia kummittelijoita: vainajat esimerkiksi voivat joutua taistelemaan viimeistä taisteluaan yhä uudelleen. Useita tarinoita on myös kerrottu vainajista, jotka näyttäytyvät ennen jonkun sukunsa jäsenen kuolemaa. Vainaja on myös voinut tuoda varoituksen tai enteen kulkutaudista, erityisesti rutosta, joka aiheutti keskiajalla paikallisia epidemioita.

\section{LOPUKSI}

Kauhutarinaksi on kirjassa tulkittu elävien maailmassa tapahtunut vainajan kohtaaminen, joka on voinut tapahtua valveilla tai unessa. Monet kertomuksista ovat hyvin lyhyitä ja osa voisi sellaisenaan jopa jäädä melko käsittämättömiksi. Joka tarinan alussa on kuitenkin taustoitus, joka sijoittaa kertomuksen tiettyyn kontekstiin ja tekee sen ymmärrettäväksi. Nämä taustatiedot sekä alku- ja loppuluvut avaavat lukijalle keskiajan kertomusperinnettä mainiolla tavalla. Lisäksi kirjan lopussa on luettelo lähteistä ja tutkimuskirjallisuudesta, joiden avulla pääsee halutessaan vaikka alkuperäistekstien äärelle tai löytää lisätietoja kiinnostavista aiheista.

Kauhuviihteeseen tottuneesta nykylukijasta keskiaikaiset kauhutarinat eivät vaikuta kovinkaan kauhistuttavilta, mutta aikalaisissa kertomukset kohtaamisista kuolleiden kanssa ovat varmaankin herättäneet oikeasti pelkoa. Monilla tarinoilla on selvästi opettavainen funktio, mutta todennäköisesti niillä on ollut myös viihteellistä käyttöarvoa. Erityisesti keskiajan kuvaajina ne ovat kiinnostavia myös nykylukijalle.

Filosofian lisensiaatti Merja Leppälahti on turkulainen folkloristi, tietokirjailija ja kriitikko. 